\title{
Effects of anti-nutritional factors on the nutritional potential of three varieties of lablab bean (Lablab purpureus) in rats \\ ${ }^{1 *}$ Soetan, K. O. and ${ }^{2} \mathrm{Abu}, \mathrm{O}$. A. \\ 'Department of Veterinary Physiology and Biochemistry, ${ }^{2}$ Department of Animal Science, University of Ibadan, Ibadan, Nigeria. *Corresponding author: kehinde.soetan@gmail.com; 08074437629 \\ Abstract
}

Twenty five Wistar strain rats weighing between 68 to $80 \mathrm{~g}$ were allotted to five dietary groups. Group I received standard protein diet which served as control, group II received a protein-free diet, which served as a negative control, while rats on III, IV and Vwere given raw Rongai Brown (RB), raw Rongai White $(R W)$ and raw Highworth Black $(H B)$ based diets as the main sources of protein, respectively. The rats were fed $10 \mathrm{~g}$ experimental diets per day for seven days. After a 3-day adaptation period, faecal samples were collected quantitatively for four days, bulked for each rat, weighed, oven-dried at $105^{\circ} \mathrm{C}$ for $24 \mathrm{hr}$, milled and stored for analyses. All the rats fed the three varieties of raw lablab beans had significant decrease $(p<0.05)$ in feed intake and final body weights as compared to the control. Rats fed on RB had the least feed intake of $19.1 \mathrm{~g} / \mathrm{wk}$ while rats on $R W$ gave the highest body weight decrease of 29.0g. The feed conversion efficiency, net protein ratio and protein efficiency ratio for all groups decreased ( $p \quad 0.05)$ significantly as compared to rats fed standard diet. The rats fed the Highworth Black gave the least value of 0.08\%. Feeding raw lablab beans to rats produced significant reductions in protein intake. The significant reduction in the various parameters used for the nutritional evaluation of these three varieties of lablab beans could be attributed to the presence of the anti-nutritional factors inherent in them which reduced the nutrient intake and utilization by the rats. Interventions of processes that reduce the antinutritional factors are therefore necessary for efficient use of lablab beans in human foods and animalfeeds.

Keywords: Lablab purpureus, Anti-nutritional factors, Wistar strain rats, net protein ratio, protein efficiency ratio

\section{Introduction}

Cowpea, soyabean, pigeon pea and lima bean are important legumes in the Nigerian diets because they are grown and used as important sources of protein (Ologhobo, 1980). Accurate analysis of the nutrients contained in them is a prerequisite for their most effective utilization and a basis for their nutritional enhancement. Among different plant species, grain legumes are considered as the major source of dietary proteins (Esenwah and Ikenebomeh, 2008). Legumes are also reported to be important sources of proteins, carbohydrates, dietary fiber and minerals consumed worldwide (Osman, 2007).

Legumes contain nutritional and antinutritional factors in addition to the secondary metabolites, which have therapeutic importance (Osman, 2007). These secondary metabolites are used as growth promoters and productivity enhancers in animal feeds (Tipu et al., 2006). The adverse effects of antinutritional factors can be reduced by applying suitable processing techniques so as to improve the nutritive value of plants. Most local farmers would prefer to feed raw lablab beans to chicken in order to eliminate transportation and processing costs (Abeke et al., 2010). Little information is available in this area, especially with regards to different varieties of lablab beans (Lablab purpureus), a newly introduced legume to Nigeria, cultivated for food/feeds in humans and animals. It has been realized 
that the available as opposed to the total amino acids of a feeding stuff is more important in determining its value in a diet (Ologhobo, 1980). This has led to a series of investigations on methods of determining the available as opposed to the total amino acids in protein. The nutrient and or chemical composition and the antinutritional factors of several legumes have been determined but data are scarce on similar information on Lablab purpureus seeds.

There is need to identify and assess the nutritive use and toxic effects of the lesser known legumes like the lablab bean. This present study was designed to supply biological information using the rat on the three varieties of lablab beans namely; Rongai Brown (RB), Rongai White (RW) and Highworth Black (HB), and to attempt to establish the effects of the inherent antinutritional factors in them, as they existed in the raw state. The main criteria for assessment were feed intake, changes in body weight, protein efficiency ratio, net protein ratio, protein retention efficiency and feed conversion efficiency

\section{Materials and methods}

Source and description of Lablab purpureus

Source: The Lablab purpureus seeds used for these studies were obtained from the International Institute of Tropical Agriculture (IITA), Moniya, Ibadan, Oyo State, Nigeria. The identification of the varieties was also done by an agronomist at IITA, Ibadan.

\section{Nutritional evaluation of lablab beans}

Twenty five Wistar strain rats weighing between 68 to $80 \mathrm{~g}$ were obtained from the Animal House of the Faculty of Veterinary Medicine, University of Ibadan, Nigeria and divided into five groups of five rats each. The cages were numbered and the rats were housed individually in stainless-steel metabolic cages (Associated Crate Ltd., England) with a wire screen bottom at the Animal House of the Department of Animal Science, University of Ibadan, Nigeria. The cages were provided with adequate devices for collection of faeces and urine. The composition of the standard diet and protein-free diet is shown in Table 1.

The feed was placed into small feeders designed to minimize scattering of the feed. Fine wire screens were placed in the plastic trays below the cages to collect the faeces and spilled over feed, and to allow the urine collection in a small urine cups. The spilled feed and faeces were separated by hand picking which enabled the separation of the particles of hair from the spilled feed and faeces.

The animals were divided on the basis of their body weights into five treatments (groups) of five rats each, such that the mean initial weights of each group were nearly similar. Rats in (group) I received standard protein diet which served as control, (group II) rats received a proteinfree diet, which served as a reference, while treatments (groups III, IV and V) were given raw Rongai Brown (RB), raw Rongai White (RW) and raw Highworth Black (HB) respectively, as the main source of protein. The standard reference protein diet was prepared according to (Sarwat et al., 1991). All the diets were served to the rats in ground form after proper mixing. The rats were fed $10 \mathrm{~g}$ experimental diets per day and feeding was done for 7 days. After a 3-days period, faecal samples were collected quantitatively daily for 4 days, bulked for each rat, weighed, dried at $105^{\circ} \mathrm{C}$ for 24 hours, ground into powder and stored according to the method of Pastuszewska et al. 2006) and of (Agbede and Aletor, 2004). Duplicate samples of faeces and diets were taken for nitrogen determination by the Kjedahl method (AOAC, 1995). Daily feed consumption was obtained by weighing the 


\section{Soetan and $\mathrm{Abu}$}

feed given and subtracting from it the weight of whatever feed remained in the dish together with the spilled over feed after 24 hours. The weights of the rats were obtained at the start of the experiment and on the seventh day. Parameters employed in determining the nutritive quality of the lablab seeds included protein efficiency ratio (PER), net protein ratio (NPR), protein retention efficiency (PRE) and feed conversion efficiency (FCE). The proximate composition of the three varieties of $L$. purpureus seeds is shown in Table 2 below.

Table 1: Composition of standard reference protein diet and protein-free diet (\%)

\begin{tabular}{llll}
\hline Ingredient & Standard & Protein diet & Protein-free diet \\
\hline Maize & 48 & 0 \\
Maize bran & 12.9 & 0 \\
Corn starch & 0 & 70 \\
Groundnut cake & 9.2 & 0 \\
Sucrose & 0 & 15 \\
Groundnut oil & 0 & 5 \\
Soyabean & 25 & 0 \\
Fish meal & 2.5 & 0 \\
Mineral & 2.0 & 4 \\
*Vitamin/trace Mineral premix & 0.1 & 1 \\
Table Salt & 0.3 & 0 \\
Cellulose & 0 & 5 \\
Total & 100 & 100 \\
\hline
\end{tabular}

*Vitamin trace mineral premix supplied per kg of diet.

Vit. A (10,000 I.U), Vit. D 3 (2000I.U), Vit. E (5I.U), Vit. K(2.24mg), riboflavin (55mg), pantothenic acid (10mg), nicotinic acid (25mg), choline (350mg), folic acid (1mg), methionine (450mg), Mn (56mg), I (1mg), Fe (20mg), Cu (10mg), Zn (50mg) Co $(1.25 \mathrm{mg})$. Maize meal and maize bran were the sources of energy while soyabean meal and fishmeal served as protein sources.

Table 2: Proximate Composition of $L$. purpureus seeds varieties

\begin{tabular}{lllllllll}
\hline Sample & $\begin{array}{l}\text { \%Crude } \\
\text { Protein }\end{array}$ & \%Crude Fat & $\begin{array}{l}\text { \%Crude } \\
\text { Fibre }\end{array}$ & \% Ash & $\begin{array}{l}\text { \% } \\
\text { Nitrogen } \\
\text { Free } \\
\text { Extract }\end{array}$ & $\begin{array}{l}\text { Gross } \\
\text { Energy } \\
\text { (Kcal/g }\end{array}$ & $\begin{array}{l}\text { \%Dry } \\
\text { Matter }\end{array}$ & $\begin{array}{l}\text { \% } \\
\text { Moisture }\end{array}$ \\
\hline Rongai & $* 24.15$ & 9.74 & 12.69 & $* 4.28$ & 39.27 & $* 3.10$ & 89.96 & 10.04 \\
Brown & \pm 0.23 & \pm 0.74 & \pm 0.12 & \pm 0.15 & \pm 0.40 & \pm 0.15 & \pm 0.31 & \pm 0.21 \\
Rongai & 23.10 & 9.56 & $* 13.12$ & 3.97 & 40.29 & 2.93 & $* 90.04$ & 9.96 \\
White & \pm 0.80 & \pm 0.38 & \pm 0.15 & \pm 0.15 & \pm 0.15 & \pm 0.59 & \pm 0.40 & \pm 0.04 \\
Highwort & 22.75 & 9.63 & 12.98 & 4.12 & $* 40.39$ & 3.00 & 89.87 & $* 10.13$ \\
h Black & \pm 0.53 & \pm 0.85 & \pm 0.15 & \pm 0.12 & \pm 0.38 & \pm 0.26 & \pm 0.19 & \pm 0.19 \\
Mean \pm & 23.33 & 9.64 & 12.93 & 4.12 & 39.93 & 3.01 & 89.96 & 10.04 \\
SEM & \pm 0.52 & \pm 0.65 & \pm 0.14 & \pm 0.14 & \pm 0.31 & \pm 0.33 & \pm 0.33 & \pm 0.15 \\
\hline
\end{tabular}

* Significant at $\mathbf{P}<\mathbf{0 . 0 5}$

Source: (Soetan and Fafunso, 2010) 
Effects of anti-nutritional factors on the nutritional potential of lablab bean (Lablab purpureus) in rats

The quantification of the anti-nutritional seeds is shown in Table 3 below. factors of the three varieties of L. purpureus

Table 3: Quantification of the Anti-nutritional Factors of $L$. purpureus seeds varieties

\begin{tabular}{|c|c|c|c|c|c|c|c|c|}
\hline Sample & $\begin{array}{l}\text { TIU/mg } \\
\text { Protein }\end{array}$ & HU/mg & $\begin{array}{l}\text { Cynogenic } \\
\text { Glycosides } \\
\mathrm{mg} / \mathrm{kg}\end{array}$ & $\begin{array}{l}\text { Oxalates } \\
\mathrm{mg} / \mathrm{g}\end{array}$ & $\begin{array}{l}\text { Phytates } \\
\mathrm{mg} / \mathrm{g}\end{array}$ & $\begin{array}{l}\text { Tannin } \\
\mathrm{mg} / \mathrm{g}\end{array}$ & $\begin{array}{l}\text { Saponin } \\
\mathrm{mg} / \mathrm{g}\end{array}$ & $\begin{array}{l}\text { Alkaloids } \\
\mathrm{mg} / \mathrm{g}\end{array}$ \\
\hline Rongai & $* 44.8$ & $23.7 \pm 0.10$ & 185.0 & 9.3 & 13.6 & $* 4.7$ & 11.3 & 4.8 \\
\hline Brown & \pm 0.57 & & \pm 0.89 & \pm 0.36 & \pm 0.27 & \pm 0.06 & \pm 0.17 & \pm 0.12 \\
\hline Rongai & 31.6 & 18.7 & $\overline{17} 5.0$ & 8.2 & 14.4 & 3.5 & 11.6 & 3.7 \\
\hline White & \pm 0.21 & \pm 0.17 & \pm 0.00 & \pm 0.12 & \pm 0.06 & \pm 0.84 & \pm 0.06 & \pm 0.15 \\
\hline Highwort & 39.5 & $* 28.6$ & $* 195.0$ & $* 9.8$ & 14.0 & 4.2 & $* 12.1$ & $* 6.8$ \\
\hline h Black & \pm 0.29 & \pm 0.06 & \pm 0.57 & \pm 0.17 & \pm 0.00 & \pm 0.81 & \pm 0.06 & \pm 0.15 \\
\hline Mean \pm & 38.6 & 23.7 & 185.0 & 9.1 & 14.0 & $\overline{4} .1$ & 11.7 & $\overline{5} .1$ \\
\hline SEM & \pm 0.36 & \pm 0.11 & \pm 0.49 & \pm 0.22 & \pm 0.11 & \pm 0.57 & \pm 0.09 & \pm 0.14 \\
\hline
\end{tabular}

$*$ Significant at $\mathbf{P}<0.05$

Source: Soetan (2012)

Assessment of the nutritional quality of the diets

The following criteria for protein utilization were worked out on the basis of analysis (for nitrogen content) of the diets and faeces respectively.

Protein Efficiency Ratio (PER): It was done according to Pellet and Young (1980). This method expresses the protein efficiency ratio as the gain in body weight per gram of protein eaten over the experimental period. $\mathrm{PER}=$ Weight gain of test animal (g) Protein consumed $(\mathrm{g})$

Net Protein Ratio (NPR): This was done by the method of Bender and Doell (1957).

$\mathrm{NPR}=$ Weight gain of test protein group+weight loss of the $\mathrm{N}$ - free diet group Protein intake $(\mathrm{g})$
Protein Retention Efficiency (PRE): This was computed as NPR value $\mathrm{x} 16$ (Bender and Doell, 1957).

Feed Conversion Efficiency (FCE): This was computed as: 1992) weight gain/loss (Agunbiade, feed intake $(\mathrm{g})$

\section{Statistical analysis}

All the results were subjected to statistical analysis using Analysis of Variance (ANOVA) and Pearson Correlation Coefficient. Results were regarded significant at $\mathrm{P}<0.05$. It is not significant when P0.05.

\section{Results}

The results of nutritional studies on $L$. purpureus Seeds are presented in Table 4.

\begin{tabular}{|c|c|c|c|c|c|c|c|c|c|}
\hline Sample & $\begin{array}{l}\text { Initial BW } \\
(\mathrm{g})\end{array}$ & $\begin{array}{l}\text { Final BW } \\
(\mathrm{g})\end{array}$ & $\begin{array}{l}\text { Change in } \\
\text { weight (g) }\end{array}$ & $\begin{array}{l}\text { Feed Intake } \\
\text { (g)/week }\end{array}$ & $\begin{array}{l}\text { PER } \\
\% \\
\end{array}$ & $\begin{array}{l}\text { NPR } \\
\% \\
\end{array}$ & $\begin{array}{l}\text { PRE } \\
\% \\
\end{array}$ & $\begin{array}{l}\text { FCE } \\
\% \\
\end{array}$ & $\begin{array}{l}\text { Protein Intake } \\
\text { (g) }\end{array}$ \\
\hline Control & $70.6 \pm 2.61$ & $\begin{array}{l}87.0 \pm 3.08 \\
(18.90)\end{array}$ & $16.4 \pm 2.70$ & $39.44 \pm 3.52$ & $1.02 \pm 0.22$ & $5.40 \pm 0.38$ & $86.18 \pm 5.80$ & $41.8 \pm 8.98$ & $1617 \pm 144.00$ \\
\hline Rongai Brown & $75.0 \pm 5.0$ & $\begin{array}{l}* 48.4+.46 \\
(35.50)\end{array}$ & $*-26.6 \pm 1.52$ & $\begin{array}{l}* 19.1 \pm 1.24 \\
(51.57)\end{array}$ & $\begin{array}{l}{ }^{*}-0.10 \pm 0.00 \\
(90.20)\end{array}$ & $\begin{array}{l}* 0.11+0.01 \\
(97.96)\end{array}$ & $\begin{array}{l}* 1.70 \pm 0.14 \\
(98.03)\end{array}$ & $\begin{array}{l}* 1.40 \pm 0.13 \\
(96.65)\end{array}$ & $\begin{array}{l}* 461.4+29.90 \\
(69.16)\end{array}$ \\
\hline Rongai White & $71.0 \pm 2.65$ & $\begin{array}{l}* 42.0 \pm 4.64 \\
(40.85)\end{array}$ & $*-29.0 \pm 2.65$ & $\begin{array}{l}* 23.5 \pm 2.60 \\
(40.42)\end{array}$ & $\begin{array}{l}{ }^{*}-0.09 \pm 0.03 \\
(91.18)\end{array}$ & $\begin{array}{l}* 0.10 \pm 0.00 \\
(98.15)\end{array}$ & $\begin{array}{l}* 1.60 \pm 0.00 \\
(98.14)\end{array}$ & $\begin{array}{l}* 1.30 \pm 0.17 \\
(96.89)\end{array}$ & $\begin{array}{l}* 543 \pm 60.24 \\
(66.42)\end{array}$ \\
\hline $\begin{array}{l}\text { Highworth } \\
\text { Black }\end{array}$ & $74.0 \pm 4.18$ & $\begin{array}{l}* 49.0 \pm .52 \\
(33.80)\end{array}$ & $*-25.0 \pm 5.00$ & $\begin{array}{l}* 23.2 \pm 1.25 \\
(41.18)\end{array}$ & $\begin{array}{l}{ }^{*}-0.08 \pm 0.03 \\
(92.16)\end{array}$ & $\begin{array}{l}* 0.10 \pm 0.00 \\
(98.15)\end{array}$ & $\begin{array}{l}* 1.64 \pm 0.09 \\
(98.10)\end{array}$ & $\begin{array}{l}* 1.10 \pm 0.19 \\
(97.37)\end{array}$ & $\begin{array}{l}* 528 \pm 28.49 \\
(67.35)\end{array}$ \\
\hline $\begin{array}{l}{ }^{*} \text { Significant } \\
\text { Key: } \\
\text { PER: Protei } \\
\text { NPR: Net P } \\
\text { PRE: Protei } \\
\text { FCE: Feed }\end{array}$ & $\begin{array}{l}\text { t }<0.05 \quad 0 \% \\
\text { Efficiency Ratio } \\
\text { tein Ratio } \\
\text { retention Efficie } \\
\text { onversion Efficie }\end{array}$ & Difference & & & & & & & \\
\hline
\end{tabular}




\section{Soetan and $A b u$}

All the rats fed the three varieties of raw lablab beans recorded significant decreases in final body weights as compared to the control rats with the rats fed the Rongai White having the highest body weight decrease of $29.0 \mathrm{~g}$. The rats fed the lablab bean varieties recorded decreases in feed intake with rats fed on Rongai Brown had the least feed intake of 19.1g/week. For the PER, all the rats fed on the lablab beans also produced significant decreases as compared to rats fed based diet (control) with rats fed the Highworth Black giving the least value of $0.08 \%$.

For the NPR, all the rats fed the lablab beans also produced significant decreases with rats fed Rongai White and Highworth Black producing the least value of $0.10 \%$. For the PRE, all the rats fed the lablab beans also produced significant reductions as compared with control rats with the rats fed the Rongai White producing the least value of $1.60 \%$. For the FCE, all the rats fed the lablab beans recorded significant decreases with rats fed Highworth Black recording the least value of $1.10 \%$. All the rats fed the three varieties of lablab beans produced significant reductions in protein intake as compared with control rats with the rats fed the Rongai Brown variety producing the least protein intake of $461.4 \mathrm{~g}$.

\section{Discussion}

The result of the protein quality studies (Table 4) showed that the feed intake of the rats placed on standard reference protein diet was higher than those of the rats placed on the three experimental diets of lablab beans (RB, RW and $\mathrm{HB}$ ), with rats fed on Rongai Brown having the least feed intake of $19.1 \mathrm{~g} /$ week. The reduction in feed intake by the rats placed on lablab beans could be attributed to the inherent anti-nutritional factors (ANF) in them, which are reported to reduce nutrient utilization and or feed intake (Osagie, 1998).

These anti-nutritional factors play a great role in limiting the wider use of many plants. Protein quality studies revealed that there were significant decreases $(\mathrm{P}<0.05)$ in the final body weight, feed intake, protein efficiency ratio (PER), net protein ratio (NPR), protein retention efficiency (PRE), feed conversion efficiency (FCE) and protein intake in the rats fed the three varieties of lablab beans compared with the rats fed the control diet. Rats fed on the raw lablab beans elicited considerable weight loss, and poor protein efficiency ratio (PER) values.

It has been reported that presence of antinutritional factors like tannin, saponin and phenolic compounds could reduce the growth of animals (Ezeabara, 2014; Ibironke, 2012, 2014).

These clearly indicate the high potency of the toxic substances in the raw state of these legumes. The poor protein utilization indices observed in the raw lablab beans indicate that the rats maintained on these legumes could not efficiently utilise the dietary proteins. Our results on growth parameters are corroborative of previous studies (Rubio et al., 1990; Apata, 1990) that the ingestion of raw navy bean, lima bean and faba bean significantly depressed growth, feed consumption, and nitrogen retention.

It was reported by (Pusztai, 1979; Ibironke and Fawale, 2015) that the inclusion of raw beans and plants in rat diets decreased protein utilization and reduced feed intake leading to weight loss. A derangement in digestion and or absorption of some dietary nutrients in rats fed raw lima bean is reported by Aletor and Fetuga (1984). From their observations, it is conceivable that the growth inhibition of rats fed raw lima bean may in part be mediated by the apparent inability of the experimental animals to 
utilize dietary nitrogen fully and perhaps other components in the diet as well.

The following factors have been claimed by different workers to affect the nutritional qualities of plant proteins, they are fertilizer and manorial treatments of plants. Thus heavier treatments result in more nitrogen content in the leaves and this could lead to increased nitrogen content of the extracted protein and increased nitrogen content of protein concentrates have been found to give higher digestibility values (Byer, 1963; Horigome and Kandatsu, 1968).

Minor quantitative differences in the amino acid spectra of the leaf proteins could also affect their nutritional values of Singh, (1970) but Pirie (1963) pointed out that this value is more limited by the digestibility values of proteins than by their amino acid composition. It was however Raymond and Tilley (1956) noticed that differences in availability of some essential amino acids of the proteins, like lysine, led to differences in the nutritional qualities of the proteins from many plant species.

When fed as the sole protein source to rats during bioassay, the L. purpureus seeds do not support growth, ostensibly because of the polyphenol levels (tannins) and other antinutrients in the seeds which may, in part, lead to poor utilization of the constituent amino acids. By implication, these seeds may not support growth if fed solely as the protein source to man.

West African countries have a low protein intake and kwashiorkor is quite common. The development of seed protein projects in this area is both desirable and feasible. The high rainfall encourages the growth of plants.

The two main reasons for protein malnutrition in Nigeria have been long been recognised as ignorance and poverty as reported by Bassir (1964). This view is also shared by other renowned Nigerian nutritionists (Oke, 1966). In an attempt to solve this problem, there is need to improve the nutritive quality of locally-available foodstuffs through better processing and enrichment (Akinrele, 1967).

The results obtained for the crude protein content of the three varieties of $L$. purpureus seeds were quite high (Table 2), with the Rongai Brown variety having the highest crude protein value of $24.15 \pm 0.23, \%$, followed by Rongai White having $23.10 \pm 0.80 \%$ and Highworth Black having the least value of $22.75 \pm 0.53 \%$ (Soetan and Fafunso, 2010). This shows that lablab beans have a good potential as a source of protein for human foods and animal feeds. If the proteins are removed from the fibrous matter and concentrated, larger quantities could be safely consumed. Legume seed protein concentrate has good potential as a protein supplement because of its high yield per unit area of land, the relatively simple method of preparation and its good nutritive value.

In comparison to cereal grains, food legumes contain more than twice the protein and yield almost as many calories per unit weight. Compared with foods of animal origin, most of these legumes contain similar amounts of protein (Akinjayeju and Enude, 2002). Since proteins constitute one of the most important nutrient present in very high amounts in the lablab seeds, methods could be developed to prepare protein isolates and various other products for diverse end uses but the antinutritional factors have to be reduced drastically.

In order to increase the biological benefits, the ease of digestion and to decrease the anti-nutritional factors in legumes, including Lablab purpureus, traditional procedures such as heating or blanching, soaking and fermentation, roasting are generally used. Most of the methods employed are based on the use of water and thermal treatments (Bressani, 2002; Diallo and Berhe, 2003). 


\section{Soetan and $\mathrm{Abu}$}

Locally, food legumes are obviously a choice as they are widely eaten. Although legumes are eaten by humans and animals, the high fibre content and the presence of toxic and or anti-nutritional factors limit the quantity that can be ingested Gupta (1987).

The results of the quantification of the antinutritional factors (Table 3) show that the three varieties of $L$. purpureus had significant levels of the different antinutritional factors (Soetan, 2012) and antinutritional factors have been reported to limit the protein intake and utilization of some essential nutrients in human foods and animal feeds (Akande et al., 2010).

The search for protein sources is of great importance in developing world where the population is growing at an accelerated rate. Plant proteins, such as legumes, will certainly play an important role in meeting the protein requirement of man as well as feeding his livestock (Apata, 1990).

In the world's search for high quality but cheap sources of protein and energy foods, increasing attention has been focused on home-grown legume seed crops which possess potential for significant contribution of nutrients particularly proteins, that can be used to improve the diets of the vast majority of people as well as in balanced and economic rations for livestock (Apata, 1990). Information on the nutritive status of these legumes is vital for their most effective utilization and a basis for their nutritional enhancement.

Attention has been drawn (NAS, 1984; Achinewhu, 1982) to several lesser-known legumes that are promising grain legumes indigenous to the tropics. Among them are the African yam bean (Sphenostylis stenocarpa), bambara groundnut (Vigna subterranea), kidney bean (Phaseolus vulgaris), tropical lima bean (Phaseolus lunatus), sword bean (Canavalia gladiata), jack bean (Canavalia ensiformis) and lablab bean (Lablab purpureus) and they are all cultivated in different localities in this country and are classified as underexploited leguminous crop seeds in Nigeria (Balogun and Fetuga, 1986).

These legumes have primary importance for supplementing the protein-deficient diets generally prevailing among Nigerians of low economic status but their nutritional possibilities have not yet been fully realized and exploited Apata and Ologhobo. (1990). They are also called minor legumes, probably because they do not enjoy a wide popularity or simply because their importance is under-estimated Agunbiade (1992). Mature dry legumes are very important in the diets of many population groups around the world Meiners et al. (1976).

Legumes should be exploited as food supplements because of their potentials as rich protein sources Peace et al. (1988). Much of the available information on the nutritive compositional data on the more commonly used local foods and feeds does not cover all these legumes and where available, needs updating. This is because of possible effects of the soil, climate, variety, processing and fertilizertreatments on their chemical composition (FAO, 1968).

The application of some processing methods like autoclaving, boiling and soaking are known to reduce or eliminate the antinutritional factors which affect the nutritional, and food quality of legumes (Udensi et al., 2005; 2007).

\section{Conclusion}

The significant reduction in the various parameters used for the nutritional evaluation of these three varieties of lablab beans could be attributed to the presence of the antinutritional factors inherent in them which reduces the nutrient intake and utilization by the rats. 
Although Lablab purpureus is newly introduced into Nigeria as a source of forage for livestock, however, the raw seeds are toxic and caution should therefore be exercised in their nutritional use. The adverse effects of anti-nutritional factors in L. purpureus could be reduced by applying appropriate and effective processing techniques so as to improve the nutritive value of the plant. Measures should therefore be taken to reduce the antinutritional and toxic factors in $L$. purpureus through various processing methods like cooking, germination, soaking, heating before use as human foods and livestock feeds.

\section{Acknowledgements}

The author appreciates the Department of Animal Science, University of Ibadan, Nigeria for permission to use the Departmental rat house to carry out this study. Appreciation also goes to the International Institute of Tropical Agriculture (IITA), Ibadan for providing the lablab beans varieties used in this study.

\section{References}

Abeke, F. O., Ogundipe, S.O., Sekoni, A.A., Dafwang, I. I., Adeyinka, I.A., Oni, O.O. and Abeke, A. 2003. "Response of Laying Hens to Dietary Levels of Cooked Lablab purpureus Beans”, Beans. Asian Journal of Animal and Veterinary Advances, 3: 916.

Achinewhu, S. C. 1982. "Composition and food potential of the African oil bean seed (Pentachthra macrophylla) and velvet been (Mucuna pruriens)". J. Food Sci., 47: 1736-1737.

Agunbiade, S.O. 1992. "The Physical,
Chemical and Nutritional Characteristics of the African Yambean. Sphenostylis stenocarpa (Hochst Ex A. Rich) Harms". Ph.D. Thesis. University of Ibadan, Nigeria.

Akande, K.E., Doma, V.D., Agu, H.O. and Adamu, H.M. 2010. Major antinutrients found in plant protein sources: Their Effect on Nutrition. Pak. J. Nutr. 9: 827832

Aletor, V. A. and Fetuga, B. L. 1984. "Effect of Graded Levels of Raw Lima Bean (Phaseolus lunatus) on Some Liver Enzyme Activity in the Rat". Nutrition Reports International. Vol. 29:565-570

Agbede, J.O. and Aletor, V.A. 2004. Chemical characterization and protein quality evaluation of leaf protein concentrates from Gliricidia sepium and Leucaena leucocephala. International Journal of Food Science and Technology. 39: 253-261.

Agunbiade, S.O. 1992. "The Physical, Chemical and Nutritional Characteristics of the Africa yam bean (Sphenostylis stenocarpa) (Hochst Ex A. Rich) Harms" Ph.D. Thesis. University of Ibadan, Nigeria, 1992.

Akinjayeju, O. and Enude, O.T. 2002. "Properties of Bambara (voandzeia subterranean.L thou) flours". Italian Journal of Food Science 1(14):53-58.

Akinrele, I. A. 1967. "Nutrient enrichment of gari". W.A. J. Biol. Applied Chem., 10: 19-23. 
AOAC 1995. Association of Official Analytical Chemists, Official methods of analysis of AOAC International. 2 vols. $16^{\text {th }}$ edition. Arlington, VA, USA, Association of Analytical Communities, 1995.

Apata, D. F. 1990. Biochemical, nutritional and toxicological assessment of some tropical legume seeds". $\mathrm{PhD}$ thesis, Dept. of Animal Science, University of Ibadan, Nigeria.

Apata, D.F. and Ologhobo, A.D. 1990. "Some aspects of the Biochemistry and Nutritive value of the African Yambean S e e d ( Sphenostylis stenocarpa)". Food Chemistry 36:271-280, 1990.

Balogun, A.M. and Fetuga, B.L. 1986. "Chemical composition of some underexploited crop seeds in Nigeria”. J. Agric Food Chem. 34: 189-192.

Bassir, O. (1964). "The use of Nigerian foods containing cultures of toxic strains of Aspergillus flavus". W. Afr. J. biol. Appl. Chem., 8, 3-15

Bender, A.E. and Doell, B.H. 1957. Biological evaluation of proteins: a new aspect”. British Journal of Nutrition, Volume 11 (2): 140-148, 1957.

Bressani, R. 2000. "Factors influencing nutritive value in food grain legumes, Mucuna compared to other grain legumes". In, Food and Feed from Mucuna, Current uses and the way forward (Editors, Flores B M, Eilittä M, Myhrman R, Carew L B and Carsky R J), Workshop, CIDICCO, CIEPCA and World Hunger Research Center, Tegucigalpa, Honduras (April 26-29, 2000), 164-188, 2002.

Byer, M. 1961. "The extraction of protein from some plants growing in Ghana". Journal of Food Science and Agriculture, 12:2030.

Diallo, O.K. and Berhe, T. 2003. "Processing of Mucuna for human food in the Republic of Guinea”. Dollery, C (Ed.). 1999. Therapeutic Drugs, 2nd Edition. Churchill Livingstone, New York, p. L39-L43, 2003.

Dingman, S.L. 2002. "Water in soils: infiltration and redistribution". Physical Hydrology. 2nd Ed. Upper saddle river, PrenticeHall, New Jersey.

Esenwah, C. N. and Ikenebomeh, M. J. 2008. "Processing effects on the nutritional and anti- nutritional contents of African locust bean (Parkia biglobosa Benth) seed". Pakistan Journal of Nutrition, 7(2): 214-217, 2008.

Ezeabara, B. 2014. "Determination of Saponin Content of VariousParts of Six Citrus species" International Research Journal of Pure and Applied Chemistry, 4(1): $1-7$

Food and Agricultural Organization of 
the United Nations (FAO) 1968. "Food Composition Tables for Use in Africa", Food and Agricultural Organization of the United Nations, FAO, Rome, 1968.

Gupta Y.P. (1987). "Anti-nutritional and toxic factors in food legumes", A review. Plant Foods for Human Nutrition. 37, 201-228.

Horigome T. and Kandatsu, M. 1968. "Biological value of proteins allowed to react with phenolic compounds in the presence of Odiphenoloxidase". Agriculture Biological Chemistry. 32: 10931102.

Ibironke, S.I., Fashakin, J.B. and B a d m u s, O.A. 2012 . "Nutritional Evaluation of Complementary Food Developed From Plant And Animal Protein Sources." Nutrition and Food Science, 42(2):111-120.

Ibironke, S.I., Adeleke, R.O. Otutu, C. A., Ajele, A. and Ige, M.M. 2014. "Nutritional Composition of Cereal filtrates based Beverages": Emerald, Nutrition and Food Science, UK: 44 (2):111-118.

Ibironke, S.I. and Fawale, O. 2015. “ Chemical analysis and animal bioassay of Hildegardia barteri (kariya seed) soy bean and maize". Annals Food Science and Technology, 16(1): 245-250.

Meiners, C.R., Derise, N.L., Lau, H.C.,
Crews, M.G., Ritchey, S.J. and Murphy, E.W. 1976. "Proximate composition and yield of raw and cooked mature dry legume". $J$. Agric. Food. Chem. 24:11221126.

National Academy of Sciences (NAS) 2010. "Legumes as Resources for the future". National Academy of Sciences of the United States, Washington D.C., 1984.

Oke, O. L. 1966. "Amaranth in Nigeria”. West Africa Pharm. 3: 122.

Ologhobo, A. D. 1980. "Biochemical and nutritional studies of cowpea and lima bean with particular reference to some inherent antinutritional components". Ph. D. Thesis, University of Ibadan, Ibadan, Nigeria.

Osagie A.U. 1998. "Anti-nutritional factors. In: Nat. Qual. Plant Foods". pp. 221-244,

Osman, M.A. 2007. "Effect of Different Processing Methods on Nutrient Composition, Anti- nutritional Factors and in vitro Protein Digestibility of Dolichos lablab bean (Lablab purpureus (L)". Pakistan Journal of Nutrition, 6(4): 299-303.

Pastuszewska， B. , Taciak, P., Ochtabiniska, A., Tusnio, A., Misztal, T., Romanowicz, K. and Morawski, A. 2006. "Nutritional value and physiological effects of soya-free diets fed to rats during growth and reproduction". Journal of Animal Physiology and Animal Nutrition, 
10:1439-1496.

Peace, R.W., Keith, M.O., Sarwar, G. and Gotting, H.G. 1988. "Effects of storage on protein nutritional quality of grain legumes". Journal of Food Science, 53: 439-441.

Pellet, P.L. and Young, V.R. 1980. "Nutritional Evaluation of protein foods". Foods and Nutrition Bulletin Supplement 4. The United Nations University, Tokyo, Japan. 104 pp., 1980.

Pirie, N.W. 1963. "Non-conventional protein sources". Recent Adv. Fd. Sci. 3:87-89.

Pusztai, A., Clarke, E.M. and King, T.P. 1979. "The Nutritional toxicity of Phaseolus vulgaris lectin". Proceedings of Nutrition Society. 38: 115 - 120, 1979.

Raymond, W.F. and Tilley, U. 1956. "The extraction of protein concentrates from leaves". Colon. Pl.Anim. Prod. 6: 3-19

Rubio, L.A., Brenes, A. and Castano, $M$. 1990. "The utilization of raw and autoclaved faba beans (Vicia $f a b a)$ and faba bean fractions in diets for growing broiler chickens". British Journal of Nutrition, 63: 419-430,

Sarwart, S. V., Katule, A. M. and Lugendo, A. J. H. 1991. "Effects of substituting dolichos bean meal with soya bean meal on the performance of broiler chicken", Livestock Research For Rural Development: $\operatorname{Vol} 3(1): 1-6$,

Singh N. 1970. "Nutritionally important pigments in leaf proteins. Paper presented at the IBP Technical Group Meeting on leaf protein". Sri. Avinashillangam Home Science College. Nov.25- 27, Coimbatore, India.

Soetan, K.O. 2012. "Comparative Evaluation of Phytochemicals in the raw and aqueous crude extracts of three varieties of Lablab purpureus seeds" African Journal of Plant Science, 6(15): 410-415.

Soetan, K. O. and Fafunso, M.A. 2010. "Studies on the Proximate and Mineral Composition of three varieties of Lablab beans (Lablab purpureus)". International Journal of Applied Agricultural Research, Vol. 5(3): 291-300.

Tipu, A., Akhtar, M.S. , Anjum, M.I. and Raja, M.L. 2006. "New dimension of medicinal plants as animal feed". Pakistan Veterinary Journal, 26: 144-148.

Udensi, E.A., Onwuka, G.I. and Oyewere, C.R. 2005. "Effect of autoclaving and boiling on some antinutritional factors in Mucuna Sloanie" Nigerian Food Journal, 23: 53-58.

Udensi, E.A., Ekwu, F.C. and Isinguzo, J.N. 2007. "Antinutrient Factors of Vegetable Cowpea (Sesquipedalis) Seeds During Thermal Processing". Pakistan Journal of Nutrition, 6(2): 194197.

Received: $10^{\text {th }}$ January, 2018 Accepted: $12^{\text {th }}$ May, 2018 